Jurnal Health Sains: p-ISSN: 2723-4339 e-ISSN: 2548-1398

Vol. 2, No. 6, Juni 2021

\title{
HUBUNGAN TINGKAT KEPATUHAN DENGAN TINGKAT KEKAMBUHAN GANGGUAN JIWA PUSKESMAS SEPATAN DAN KEDAUNG TANGERANG TAHUN 2020
}

\author{
Amran Sebayang \\ Sekolah Tinggi Ilmu Kesehatan (STIKes) YATSI Tangerang Banten, Indonesia \\ Email: amransebayang474@gmail.com
}

\begin{tabular}{l}
\hline ARTIKEL INFO \\
\hline Diterima: 5 Juni 2021 \\
Direvisi: 15 Juni 2021 \\
Disetujui: 25 Juni 2021 \\
\hline
\end{tabular}

\section{Keywords:}

mental disorder clients;

recurrence

\begin{abstract}
In patients with mental disorders, almost all patients experience recurrence repeatedly. Data from medical records at the Sepatan Health Center, the presentation of recurrence of mental illness patients at the Sepatan Health Center in 2019 was $26.8 \%$. The same was true for the Kedaung Barat Puskesmas at $22 \%$. To determine therelationship between the level of control adherence and the recurrence rate of mental disorders clients at the Sepatan Public Health Center and the Kedaung Barat Tangerang Public Health Center in 2020. Including an analytical survey with a cross sectional approach. The population in this study were all schizophenia patients at the Sepatan Health Center and the Kedaung Barat Health Center, Tangerang Regency in 2020, as many as 109 people. Samples were taken based on the slovin as many as 109 respondents. This study used univariate and bivariate analysis with the Chi Square test. Based on univariate analysis of 109 people, the majority withmental disorders clients who did not relapse were 58 people (53.2\%), and the adherence level of adherent controls was 61 people (56\%). The results of the bivariate analysis with the chi square test found that there was a relationship between control compliance ( $p$-value 0.000 ), with mental disorders client recurrence. There is a relationship between the level ofcontrol adherence with the recurrence rate of mentaldisorders clients, with a possible rate of 29,871. It is hoped that it can provide information and be able to provide education on nursing services, especially for the client's family of mental disorders to motivate clients with mental disorders to comply with control.
\end{abstract}

\begin{abstract}
ABSTRAK
Pada pasien gangguan jiwa, hampir semua pasien mengalami kekambuhan berulang kali. Data dari catatan medik di Puskesmas Sepatan presentasi kekambuhan pasien gangguan jiwa di Puskesmas Sepatan tahun 2019 sebesar 26,8\%. Begitu pula di Puskesmas Kedaung Barat sebesar $22 \%$. Tujuan untuk mengetahui hubungan tingkat kepatuhan kontrol dengan tingkat kekambuhan klien gangguan jiwa di

Puskesmas Sepatan dan Puskesmas Kedaung Barat
\end{abstract}

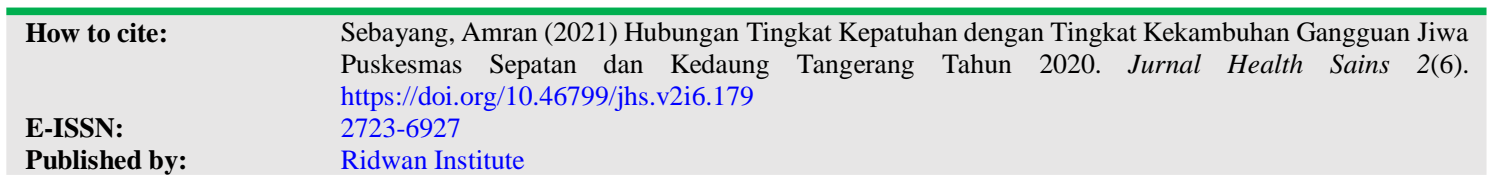


Kata Kunci:

klien gangguan jiwa;

kekambuhan
Tangerang tahun 2020. Termasuk survey analitik dengan pendekatan cross sectional. Populasi dalam penelitian ini adalah seluruh pasien skizofenia di Puskesmas Sepatan dan Puskesmas Kedaung Barat Kabupaten Tangerang tahun 2020, yaitu sebanyak 110 orang. Sampel diambil berdasarkan rumus slovin yaitu sebanyak 109 responden. Penelitian ini menggunakan analisis univariat dan bivariat dengan uji $C h i$ Square. Berdasarkan analisis univariat dari 109 orang, mayoritas dengan klien gangguan jiwa yang tidak kambuh sebanyak 58 orang $(53,2 \%)$, dan tingkat kepatuhan kontrol yang patuh sebanyak 61 orang $(56 \%)$. Hasil analisis bivariat dengan uji chi square didapat ada hubungan antara kepatuhan kontrol (p-value 0,000), dengan kekambuhan klien gangguan jiwa. Kesimpulan penelitian ada hubungan antara tingkat kepatuhan kontrol dengan tingkat kekambuhan klien gangguan jiwa, dengan tingka tkemungkin terjadi sebesar 29,871. Diharapkan dapat memberikan informasi dan dapat memberikan edukasi pelayanan keperawatan khususnya pada keluarga klien gangguan jiwa untuk memotivasi klien gangguan jiwa untuk patuh kontrol.

\section{Pendahuluan}

Gangguan jiwa adalah gangguan mental yang sangat berat. Gangguan ini ditandai dengan gejala-gejala positif seperti pembicaraan yang kacau, delusi, halusinasi, gangguan kognitif dan persepsi, gejala-gejala negatif seperti avolition (menurunnya minat dan dorongan), berkurangnya keinginan bicara dan miskinnya isi pembicaraan, menunjukkan afek yang datar serta terganggunya relasi personal. Penyebab pasti skizofrenia belum ditemukan namun ada beberapa ada beberapa faktor dari hasil penelitian yang dilaporkan saat ini berhubungan dengan kejadian skizofrenia. Pertama dari faktor biologi, kedua faktor biokimia, ketiga faktor genetika, dan faktor terakhir yaitu faktor keluarga dimana kekacauan dan dinamika keluarga memegang peranan penting dalam menimbulkan kekambuhan dan mempertahankan remisi (Amir et al., 2013).

Data WHO (World HealthOrganization) tahun 2011 menyatakan bahwa masalah kesehatan jiwa menempati urutan kedua setelah penyakit infeksi. WHO juga memperkirakan ada sekitar 450 juta orang di dunia yang mengalami gangguan kesehatan jiwa atau skizofrenia. Di Amerika Serikat dari 250 juta penduduknya di perkirakan 16 juta menderita skizofrenia. Sedangkan hasil Survei Kesehatan Mental Rumah Tangga (SKMRT) tahun 2018 di Indonesia menyatakan bahwa 7 orang dari 1000 penduduk mengalami skizofrenia, itu artinya dari satu kepala keluarga maka ada satu anggota keluarga yang mengalami skizofrenia dan diperkirakansejak awal tahun 2011 jumlah penduduk yang mengalami skizofrenia sebesar $25 \%$ dari populasi penduduk di Indonesia (Yosep et al., 2021).

Data Provinsi Banten, berdasarkan hasil (Riskesdas, 2013) menunjukkan bahwa, terdapat 1,7 per 1000 orang mengalami skizofrenia atau sekitar 3.858 penduduk mengalami skizofrenia. Masalah yang dihadapi, yaitu banyaknya masyarakat yang membutuhkan pelayanan kesehatan jiwa dan masalah dalam penanganan penderita skizofrenia adalah tingginya angka kekambuhan. 
Hubungan Tingkat Kepatuhan dengan Tingkat Kekambuhan Gangguan Jiwa Puskesmas Sepatan dan Kedaung Tangerang Tahun 2020

Jumlah penderita skizofrenia di Kabupaten Tangerang, Banten, terus meningkat. Data di Dinas Kesehatan (Dinkes) setempat menyebutkan, sejak 2017 hingga sekarang, tercatat ada 4.000 orang dengan skizofrenia (Kemenkes, 2018).

Gangguan jiwa sangat berbahaya walaupun tidak langsung menyebabkan kematian, namun akan menimbulkan penderitaan yang mendalam bagi individu dan beban yang berat bagi keluarga. Gangguan kesehatan jiwa bukan hanya gejala kejiwaan saja tetapi sangat luas dari mulai yang ringan seperti kecemasan dan depresi, malas bekerja, sering tidak masuk kerja, tidak bisa bekerja sama dengan teman sekerja, sering marahmarah, ketagihan Napza, Alkohol, Rokok, kepikunan pada orang tua, Autis pada anak sampai kepada yang sangat berat seperti Skizofrenia. Beban yang ditimbulkan oleh gangguan jiwa sangat besar. Hasil studi Bank Dunia tahun 2008 menunjukkan, global burden of disease akibat masalah kesehatan jiwa mencapai $8,1 \%$, jauh lebih tinggi dari tuberklosis $(7,2 \%)$, kanker $(5,8 \%)$, penyakit jantung $(4,4 \%)$, atau malaria $(2,6 \%)$. Meski bukan penyebab utama kematian, gangguan jiwa merupakan penyebab utama disabilitas pada kelompok usia paling produktif, yakni antara 15-44 tahun. Dampak sosialnya sangat serius berupa penolakan, pengucilan, dan diskriminasi. Begitu pula dampak ekonomi berupa hilangnya hari produktif untuk mencari nafkah bagi penderita maupun keluarga yang harus merawat, serta tingginya biaya perawatan yang harus ditanggung keluarga maupun masyarakat (Yosep et al., 2021).

Faktor penyebab terjadinya gangguan jiwa bervariasi tergantung pada jenis-jenis gangguan jiwa yang dialami. Secara umum gangguan jiwa disebabkan karena adanya tekanan psikologis yang disebabkan oleh adanya tekanan dari luar individu maupun tekanan dari dalam individu. Beberapa hal yang menjadi penyebab adalah ketidaktahuan keluarga dan masyarakat terhadap jenis gangguan jiwa ini (Al-Hawari et al., 2017).

Beberapa diagnosis gangguan jiwa bersifat kronis dan membutuhkan pengobatan dalam jangka waktu lama (lebih dari 1 tahun). Namun demikian akibat kurang patuh maka angka kekambuhan pasien gangguan jiwa tinggi. Angka kekambuhan tersebut dapat diturunkan secara signifikan dengan pemberdayaan keluarga. Penelitian yang dilakukan oleh (Abdel-Salam et al., 2016) menemukan bahwa dengan adanya pelatihan pada keluarga tentang cara mengontrol perilaku kekerasan (violence) pasiengangguan jiwa menghasilkan lama rawat yang lebih pendek di rumah sakit dan durasi kekambuhan yang lebih panjang.

Kekambuhan (relaps) adalah kondisi pemunculan kembali tanda dan gejala satu penyakit setelah mereda. Sekitar 33\% penderita skizofrenia mengalami ke-kambuhan dan sekitar $12,1 \%$ kembali mengalami rawat penyakit skizofrenia cenderung menjadi kronis, sekitar 20 hingga $40 \%$ penderita skizofrenia yang diobati. Beberapa faktor yang memengaruhi kekambuhan penderita gangguan jiwa, antara lain meliputi ekspresi emosi keluarga, pengetahuan keluarga, ketersediaan pelayanan kesehatan, dan kepatuhan kontrol juga kepatuhan minum obat (Putri et al., 2013).

Kepatuhan adalah sebuah istilah yang menggambarkan bagaimana pasien mengikuti petunjuk dan rekomendasi terapi dari perawat atau dokter. Ketidakpatuhan pasien gangguan jiwa terhadap regimen terapeutik: pengobatan menjadi masalah global di seluruh dunia. Hanya $25 \%$ sampai $50 \%$ pasien gangguan jiwa yang patuh terhadap pengobatan. Supaya masalah ketidakpatuhan ini dapat diatasi maka perawat harus memahami faktor-faktor yang menyebabkan ketidakpatuhan. Adapun penyebab ketidakpatuhan pasien untuk kontrol juga terapi obat adalah sifat penyakit yang kronis sehingga pasien merasa bosan 
minum obat, berkurangnya gejala, tidak pasti tentang tujuan terapi, harga obat yang mahal, tidak mengerti tentang instruksi penggunaan obat, dosis yang tidak akurat dalam mengkonsumsi obat, dan efek samping yang tidak menyenangkan (Wardhani \& Sulistyani, 2012).

Pada pasien gangguan jiwa, hampir semua pasien mengalami kekambuhan berulang kali sehingga mengakibatkan defisit ketrampilan personal dan vokasional. Terjadinya kekambuhan pada pasien skizofrenia tentu akan merugikan dan membahayakan pasien, keluarga, dan masyarakat.

Ketika tanda-tanda kekambuhan muncul, pasien bisa saja berperilaku menyimpang seperti mengamuk, bertindak anarkis seperti menghancurkan barang-barang atau yang lebih parah lagi pasien akan melukai bahkan membunuh orang lain atau dirinya sendiri. Jika hal tersebut terjadi masyarakat akan menganggap bahwa gangguan yang diderita pasien tersebut sudah tidak bisa disembuhkan lagi. Keluarga pun akan dirugikan dari segi materi karena jika pasien mengalami rehospitalisasi atau kembali menjalani rawat inap di rumah sakit jiwa maka akan banyak biaya yang harus mereka keluarkan untuk pengobatan (Amelia, 2013).

Hasil penelitian (Sari \&
Sholihah'Atiqoh, 2020) tentang Faktor-Faktor Yang Berhubungan Dengan Terjadinya Kekambuhan Pada Penderita Gangguan Jiwa Di Wilayah Kerja Puskesmas Sungai Dareh Kabupaten Dharmasraya. Hasil penelitian menyebutkan ada hubungan antara kepatuhan dengan kekambuhan pasien penderita ganggun jiwa. Hasil penelitian ini dibuktikan melalui uji statistik chi-square dimana diperoleh $\mathrm{p}$ value 0,000 yang berarti $\mathrm{p}$-value $<\alpha(0,05)$. Hasil penelitian ini juga selaras dengan penelitian yang dilakukan (AbdelSalam et al., 2016), dimana ditemukan adanya hubungan antara kepatuhan dengan kekambuhan pasien penderita ganggun jiwa. Hasil uji statistik diperoleh $\mathrm{p}$ value 0,007. Dengan demikian tingkat kecemasan dapat berpengaruh pada kualitas tidur pasien pre operasi.

Berdasarkan studi awal peneliti pada bulan Februari tahun 2020 di Puskesmas Sepatan dan Puskesmas Kedaung Barat Kabupaten Tangerang menunjukkan data yang diperoleh dari catatan medik di

Puskesmas Sepatan, pasien gangguan jiwa tahun 2018 berjumlah 45 pasien. Mengalami peningkatan di tahun 2019 menjadi 49 pasien.

Sedangkan di Puskesmas Kedaung Barat pasien gangguan jiwa tahun 2018 berjumlah 46 pasien. Mengalami peningkatan di tahun 2019 menjadi 48 pasien. Presentasi kekambuhan pasien skizofrenia di Puskesmas Sepatan tahun 2019 sebesar 26,5\% perbulannya terhitung dari banyaknya pasien

skizofrenia 49 orang dan yang mengalami kekambuhan sebanyak 13 orang. Begitu pula di Puskesmas Kedaung Barat prevalensi kekambuhan pasien skizofrenia tahun 2019 di Puskesmas Sepatan sebesar 20,8 \% perbulannya terhitung dari banyaknya pasien skizofrenia 48 orang dan yang mengalami kekambuhan sebanyak 10 orang. Berdasarkan uraian ini maka peneliti tertarik untuk melakukan penelitian tentang "Hubungan

Tingkat Kepatuhan Kontrol Dengan Tingkat Kekambuhan Klien Gangguan Jiwa di Puskesmas Sepatan dan Puskesmas Kedaung Barat Tangerang".

Tujuan penelitian untuk mengetahui hubungan tingkat kepatuhan kontrol dengan tingkat kekambuhan klien gangguan jiwa di Puskesmas Sepatan dan Puskesmas Kedaung Barat Tangerang tahun 2020.

Hasil penelitian ini diharapkan dapat menjadi referensi/sumber kepustakaan serta sebagai bahan masukan untuk peneliti selanjutnya dalam melakukan penelitian yang berkaitan dengan manajemen keperawatan khususnya yang berhubungan dengan tingkat 
Hubungan Tingkat Kepatuhan dengan Tingkat Kekambuhan Gangguan Jiwa Puskesmas Sepatan dan Kedaung Tangerang Tahun 2020

kepatuhan kontrol dan tingkat kekambuhan klien gangguan jiwa.

\section{Metode Penelitian}

Desain Penelitian yang dipakai adalah desain penelitian survey analitic yaitu dengan tujuan untuk mengetahui hubungan tingkat kepatuhan kontrol dengan tingkat kekambuhan klien gangguan jiwa di Puskesmas Sepatan dan Puskesmas Kedaung Barat Tangerang tahun 2020. Desain penelitian ini dilakukan dengan pendekatan Cross Sectional yaitu pengambilan data Variabel Dependen dan Variabel independen yang dilakukan pada saat yang bersamaan (Notoatmdojo, 2014).

Penelitian ini dilaksanakan di Puskesmas Sepatan dan Puskesmas Kedaung Barat Tangerang. Penelitian dilaksanakan pada bulan Maret-Mei 2020.

Populasi dalam penelitian ini adalah seluruh pasien gangguan jiwa di Puskesmas Sepatan dan Puskesmas Kedaung Barat Tangerang tahun 2019, yaitu sebanyak 110 orang.

\section{Hasil dan Pembahasan}

\section{A. Hasil Penelitian}

Proses penelitian yang dilakukan ini bertujuan untuk mengetahui hubungan tingkat kepatuhan kontrol dengan tingkat kekambuhan klien gangguan jiwa di Puskesmas Sepatan dan Puskesmas Kedaung Barat Tangerang tahun 2020.

1. Analisis Univariat

Tabel 1

Distribusi Frekuensi Tingkat

Kekambuhan Dan Tingkat

Kepatuhan Kontrol Klien Gangguan

Jiwa Di Puskesmas Sepatan Dan

Puskesmas Kedaung Barat

Kabupaten Tangerang

Tahun $2020(n=97)$

\begin{tabular}{lrr}
\hline \multicolumn{1}{c}{ Variabel } & \multicolumn{2}{c}{ Frekuensi } \\
\cline { 2 - 3 } & \multicolumn{2}{c}{$\mathbf{~ n}$} \\
\hline Tingkat Kekambuhan & & \multicolumn{2}{c}{5} \\
Tidak Kambuh & 58 & 53,2 \\
\hline
\end{tabular}

Jurnal Health Sains, Vol 2, No 5, Mei 2021

\begin{tabular}{lcc}
\hline Kambuh & 51 & 46,8 \\
\hline Jumlah & $\mathbf{1 0 9}$ & $\mathbf{1 0 0}$ \\
\hline Tingkat Kepatuhan & & \\
Kontrol & 61 & 56 \\
$\begin{array}{l}\text { Patuh Tidak } \\
\text { Patuh }\end{array}$ & 48 & 44 \\
Jumlah & $\mathbf{1 0 9}$ & $\mathbf{1 0 0}$ \\
\hline
\end{tabular}

Berdasarkan tabel 1 dapat dilihat bahwa dari 109 orang di Puskesmas Sepatan dan Puskesmas Kedaung Barat Kabupaten Tangerang tahun 2020, diketahui mayoritas dengan klien gangguan jiwa yang tidak kambuh sebanyak 58 orang $(53,2 \%)$, dantingkat kepatuhan kontrol yang patuh sebanyak 61 orang $(56 \%)$.

2. Analisis Bivariat

a. Uji Normalitas

Uji normalitas merupakan uji yang dilakukan terhadap data hasil penelitian untuk mengetahui apakah data yang telah dibuat berdistribusi normal atau tidak. Uji normalitas memakai uji Kolmogorov-Smirnov dikarenakan sampel dalam penelitian ini yaitu 109 orang (sampel > 50). Hasil dari uji normalitas untuk menentukan nilai apa yang dipakai, apabila hasil berdistribusi normal maka nilai yang digunakan yaitu nilai mean, dan apabila berdistribusi tidak normal maka nilai yang digunakan yaitu median.

Hasil dari uji normalitas pada penelitian ini untuk mengetahui apakah variabel kepatuhan kontrol dengan tingkat kekambuhan klien gangguan jiwa berdistribusi normal atau tidak, sebagai berikut di bawah ini :

Tabel 2

\section{Hasil uji Normalitas \\ One-Sample Kolmogorov- Smirnov Test}

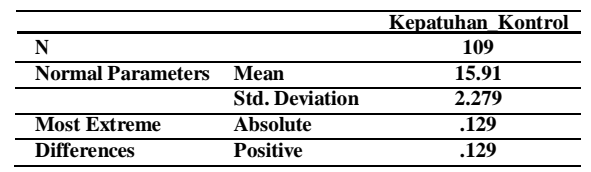




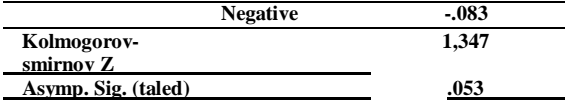

Berdasarkan tabel 2 diketahui pada point a bahwa data berdistribusi normal dengan nilai uji normalitas Kolmogorov-Smirnov Z. Hal ini menandakan bahwa kepatuhan kontrol dengan tingkat kekambuhan klien gangguan jiwa berdistribusi normal. Dengan demikian maka nilai yang digunakan yaitu mean.

Tabel 3

Hubungan Tingkat Kepatuhan Kontrol Dengan Tingkat

Kekambuhan Klien Gangguan

Jiwa Di Puskesmas Sepatan Dan

Puskesmas Kedaung Barat

Kabupaten Tangerang Tahun

\begin{tabular}{|c|c|c|c|c|c|c|c|}
\hline \multirow{3}{*}{$\begin{array}{c}\text { Tingkat } \\
\text { Kepatuhan }\end{array}$} & \multicolumn{5}{|c|}{2020} & \multirow{4}{*}{$\begin{array}{c}\mathrm{p}- \\
\text { Value }\end{array}$} & \multirow{3}{*}{$\begin{array}{c}\text { OR } \\
(95 \% \mathrm{CI}\end{array}$} \\
\hline & \multicolumn{4}{|c|}{ Kekambuhan } & \multirow[t]{2}{*}{ Jumlah } & & \\
\hline & & Tidak & & Ya & & & \\
\hline Kontrol & $\mathrm{n}$ & $\%$ & $\mathrm{n}$ & $\% \quad \mathrm{n}$ & $\%$ & & \\
\hline Patuh & 51 & 83,6 & 10 & 16,461 & 100 & \multirow{3}{*}{0.000} & 29,871 \\
\hline Tidak $\mathrm{p}$ & 7 & 14,6 & 41 & 85,448 & 100 & & $(10,456$ \\
\hline Total & 58 & 53,2 & 51 & 46,8109 & 100 & & $85,339)$ \\
\hline
\end{tabular}

Berdasarkan tabel 3 diketahui bahwa, pada klien gangguan jiwa yang patuh kontrol dari 61 orang, sebagian besar dengan tidak mengalami kekambuhan yaitu sebanyak 51 orang $(83,6 \%)$. Sedangkan pada klien gangguan jiwa yang tidak patuh kontrol dari 48 orang, sebagian besar dengan yang mengalami kekambuhan yaitu sebanyak 41 orang $(85,4 \%)$.

Hasil uji statistik dengan Chi Square diperoleh $\mathrm{p}$-value $=0,000$ artinya $\mathrm{p}<\alpha(0,05)$, maka dapat disimpulkan bahwa Ho ditolak, berarti ada hubungan antara tingkat kepatuhan kontrol dengan tingkat kekambuhan klien gangguan jiwa di Puskesmas Sepatan dan Puskesmas Kedaung Barat Kabupaten
Tangerang tahun 2020. Berdasarkan nilai Risk Etimate diperoleh nilai OR 29,871 artinya klien gangguan jiwa yang tidak patuh kontrol memiliki peluang lebih besar mengalami kekambuhan sebanyak 30 kali

\section{B. Pembahasan}

Berdasarkan hasil penelitian diketahui bahwa dari 109 orang di Puskesmas Sepatan dan Puskesmas Kedaung Barat Kabupaten Tangerang tahun 2020, diketahui mayoritas dengan klien gangguan jiwa yang tidak kambuh sebanyak 58 orang $(53,2 \%)$

Hasil penelitian ini sesuai dengan penelitian yang dilakukan oleh (Mastiyas, 2018) tentang Hubungan Resiliensi Keluarga dengan Kekambuhan Pada Orang Dengan Gangguan Jiwa (ODGJ). Hasil penelitian menunjukkan bahwa dari 258 orang sebagian besar pasien yang tidak mengalami kekambuhan yaitu sebanyak 148 orang $(57,4 \%)$. Namun hasilpenelitian ini tidak sesuai dengan penelitian yang dilakukan oleh (Sari \& Sholihah'Atiqoh, 2020) tentang faktor- faktor yang berhubungan dengan terjadinya kekambuhan pada penderita gangguan jiwa di wilayah kerja Puskesmas Sungai Dare Kabupaten Dharmasraya. Hasil penelitian menunjukkan bahwa dari 40 orang sebagian besar pasien yang mengalami kekambuhan yaitu sebanyak 21 orang $(52,5 \%)$.

Menurut (Bharucha, 2015) yang menyatakan bahwa Kekambuhan diartikan sebagai suatu keadaan dimana apabila seorang pasien gangguan jiwa yang telah menjalani rawat inap di rumah sakit jiwa dan diperbolehkan pulang kemudian kembali menunjukkan gejala-gejala sebelum dirawat inap. Setiap relaps yang terjadi berpotensi membahayakan bagi pasien dan keluarganya, maka apabila 
Hubungan Tingkat Kepatuhan dengan Tingkat Kekambuhan Gangguan Jiwa Puskesmas Sepatan dan Kedaung Tangerang Tahun 2020

relaps terjadi maka pasien harus kembali melakukan perawatan inap di rumah sakit jiwa (rehospitalisasi) untuk ditangani oleh pihak yang berwenang.

Hal ini diperkuat dengan teori dari (Maramis, 2013) bahwa seseorang yang mempengaruhi emosi, pikiran atau tingkah laku mereka, diluar kepercayaan budaya dan kepribadian mereka, dan menimbulkan efek yang negative bagi kehidupan mereka atau kehidupan keluarga mereka. Tim kesehatan menyatakan bahwa klien menyimpan catatan harian mengenai perasaan danperilakunya sehingga mereka secara signifikan dapat mengalami perubahan dan peringatan tanda akan kekambuhannya.

Menurut peneliti banyaknya responden yang tidak mengalami kekambuhan dikarenakan antara klien, keluarga klien dan tenaga kesehatan sudah bersinergi dengan baik, sehingga angka kekambuhan bisa diminimalir.

Berdasarkan hasil penelitian diketahui bahwa dari 109 orang di Puskesmas Sepatan dan Puskesmas Kedaung Barat Kabupaten Tangerang tahun 2020, diketahui mayoritas dengan klien gangguan jiwa yang tingkat kepatuhan kontrol patuh sebanyak 61 orang $(56 \%)$.

Hasil penelitian ini sesuai dengan penelitian yang dilakukan oleh (AbdelSalam et al., 2016) tentang Faktor-Faktor Yang Mempengaruhi Kekambuhan Pasien Jiwa Di Rumah Sakit Khusus Daerah (RSKD) Prov Sul-Sel. Hasil penelitian menunjukkan bahwa dari 50 orang sebagian besar pasien yang patuh kontrol yaitu sebanyak 31 orang (62\%).

Namun hasil penelitian ini tidak sesuai dengan penelitian yang dilakukan oleh (Santika et al., 2017) tentang hubungan motivasi keluarga dan kepatuhan kontrol berobat klien gangguan jiwa. Hasil penelitian menunjukkan bahwa dari 30 orang sebagian besar pasien yang tidak patuh kontrol sebagian besar pasien yang tidak patuh yaitu sebanyak 16 orang $(53,3 \%)$.

Menurut (Fenton et al., 2012) yang menyatakan bahwa Kepatuhan merupakan suatu proses yang sangat dipengaruhi oleh lingkungan tempat pasien tinggal, tenaga kesehatan, dan kepedulian sistem kesehatan. Kepatuhan juga berhubungan dengan cara yang ditempuh oleh pasien dalam menilai kebutuhan pribadi untuk pengobatan berbagai kompetisi yang diperlukan, diinginkan, dan perhatian (efek samping, cacat, kepercayaan, biaya, dan lain-lain). Kepatuhan tidak hanya dipengaruhi oleh pasien, kepatuhan dipengaruhi juga oleh tenaga kesehatan yang tersedia, pemberian pengobatan yang kompleks, sistem akses dan pelayanan kesehatan.

Menurut peneliti banyaknya responden yang patuh untuk kontrol dikarenakan keluarga pasien sudah banyak mengetahui atau terpapar informasi mengenai gangguan jiwa, jadi timbul kesadaran pada keluarga pasien untuk membawa anggota keluarganya yang mengalami gangguan jiwa untuk kontrol.

Berdasarkan hasil penelitian diketahui bahwa, pada klien gangguan jiwa yang patuh kontrol dari 61 orang, sebagian besar dengan tidak mengalami kekambuhan yaitu sebanyak 51 orang $(83,6 \%)$. Sedangkan pada klien gangguan jiwa yang tidak patuh kontrol dari 48 orang, sebagian besar dengan yang mengalami kekambuhan yaitu sebanyak 41 orang $(85,4 \%)$. Hasil uji Chi Square $\mathrm{p}$ - value $=$ 0,000 yang berarti ada hubungan antara tingkat kepatuhan kontrol dengan tingkat kekambuhan klien gangguan jiwa, dengan tingkat kemungkinan terjadi nilai OR 29,871 artinya klien gangguan jiwa yang tidak patuh kontrol memiliki peluang 
lebih besar mengalami kekambuhan sebanyak 30 kali.

Hasil penelitian ini sesuai dengan penelitian (Hardisal, 2017) yang berjudul faktor yang berhubungan dengan kekambuhan penderita skizofrenia di Rumah Sakit Jiwa Tampan Provinsi Riau, dimana hasil penelitian menunjukkan bahwa adanya hubungan antara kepatuhan minum obat (p-value 0,001) dengan skizofrenia pada pasien di Rumah Sakit Jiwa Tampan Provinsi Riau.

Hasil penelitian ini juga sesuai dengan penelitian (Aprilis, 2017) yang berjudul faktor-faktor yang berhubungan dengan kekambuhan pasien gangguan jiwa di Rumah Sakit Jiwa Tampan Provinsi Riau tahun 2016, dimana hasil penelitian menunjukkan bahwa dari hasil uji statistik diketahui adanya hubungan yang signifikan antara kepatuhan minum obat(pvalue 0,001 ) dengan skizofrenia padapasien di Rumah Sakit Jiwa TampanProvinsi Riau.

Hasil penelitian ini sesuai dengan pernyataan (Fenton et al., 2012) yang menyatakan bahwa Kepatuhan merupakan suatu proses yang sangat dipengaruhi oleh lingkungan tempat pasien tinggal, tenaga kesehatan, dan kepedulian sistem kesehatan. Kepatuhan juga berhubungan dengan cara yang ditempuh oleh pasien dalam menilai kebutuhan pribadi untuk pengobatan berbagai kompetisi yang diperlukan, diinginkan, dan perhatian (efek samping, cacat, kepercayaan, biaya, dan lain-lain). Kepatuhan tidak hanya dipengaruhi oleh pasien, kepatuhan dipengaruhi juga oleh tenaga kesehatan yang tersedia, pemberian pengobatan yang kompleks, sistem akses dan pelayanan kesehatan.

Dalam pernnyataannya yang lain (Fenton et al., 2012) menyatakan bahwa adapun faktor-faktor yang berhubungan dengan kepatuhan untuk kontrol dan berkaitan dengan penyakit, yaitu : durasi penyakit, penyakit dengan durasi lama atau penyakit kronis yang berhubungan dengan tingkat kepatuhan rendah. Kepatuhan terhadap pengobatan akan menurun seiiring dengan durasi terapi yang semakin bertambah. Beberapa penelitian menunjukkan bahwa pasien dengan tingkat keparahan penyakit yang tinggi cenderung akan lebih patuh terhadap pengobatan yang diberikan.

Hal ini diperkuat dengan pernyataan (Gunawan et al., 2012) yang menyatakan bahwa Ketidakpatuhan dalam meminum obat akan meningkatkan risiko kekambuhan hingga 92\%. Harus dikatakan bahwa pasien yang teratur minum obat selama 1 tahun pun tetap dapat jatuh dalam kondisi kekambuhan, walaupun kekambuhan baru bisa terjadi setelah putus obat selama beberapa minggu hingga bulan, hanya saja jika pasien patuh terhadap pengobatan maka waktu remisi atau bebas gejala dapat bertahan lebih lama dan gejala kekambuhan tidak akan seburuk episode pertama skizofrenia.

Menurut peneliti adanya hubungan antara kepatuhan kontrol dengan kekambuhan klien gangguan jiwa dikarenakan sebagian besar klien gangguan jiwa patuh untuk melakukan kontrol, dengan didukung oleh keluarga yang baik, sehingga klien patuh untuk minum obat, hal ini akan memberikan dampak yang baik pada pasien, karena dengan adanya kepatuhan minum obat maka pasien tersebut bisa sembuh, setidaknya bisa melakukan interaksi dengan orang lain. Kepatuhan tersebut, tidak lepas dari peran keluarga, sehingga pasien yang patuh pada pengobatan akan memberikan suatu kesembuhan pada seorang pasien. 
Hubungan Tingkat Kepatuhan dengan Tingkat Kekambuhan Gangguan Jiwa Puskesmas

Sepatan dan Kedaung Tangerang Tahun 2020

\section{Kesimpulan}

Berdasarkan hasil penelitian dan pembahasan yang telah diuraikan pada bab sebelumnya, dapat diketahui bahwa dari 109 orang klien gangguan jiwa di Puskesmas Sepatan dan Puskesmas Kedaung Barat Kabupaten Tangerang tahun 2020, maka dapat disimpulkan berdasarkan distribusi frekuensi dari 109 orang, diketahui mayoritas dengan klien gangguan jiwa yang tidak kambuh sebesar 53,2\%. Berdasarkan distribusi frekuensi dari 109 orang, diketahui mayoritas dengan klien gangguan jiwa yang tingkat kepatuhan kontrol patuh sebesar 56\%. Terdapat hubungan yang bermakna antara tingkat kepatuhan kontrol dengan tingkat kekambuhan klien gangguan jiwa (p-value 0,000), dengan nilai OR 29,871.

\section{BIBLIOGRAFI}

Abdel-Salam, O. M. E., Youness, E. R., Morsy, F. A., Yassen, N. N., Mohammed, N. A., \& Sleem, A. A. (2016). Methylene Blue Protects Against Toluene-Induced Brain Damage: Involvement Of Nitric Oxide, Nf-Kb, And Caspase-3. Reactive Oxygen Species, 2(5), 371-387. Google Scholar

Al-Hawari, $\quad$ F., Alufeishat, A., Alshawabkeh, M., Barham, H., \& Habahbeh, M. (2017). The Software Engineering Of A Three-Tier WebBased Student Information System (Mygju). Computer Applications In Engineering Education, 25(2), 242263. Google Scholar

Amelia, K. (2013). Hubungan Pengetahuan Makanan Dan Kesehatan Dengan Frekuensi Konsumsi Makanan Jajanan Pada Anak Sekolah Dasar Pembangunan Laboratorium Universitas NegeriPadang. E-Journal Home Economic AndTourism, 2(1). Google Scholar

Amir, E. D., Davis, K. L., Tadmor, M. D.,
Simonds, E. F., Levine, J. H., Bendall, S. C., Shenfeld, D. K., Krishnaswamy, S., Nolan, G. P., \& Pe'er, D. (2013). Visne Enables Visualization Of High Dimensional Single-Cell Data And Reveals Phenotypic Heterogeneity Of Leukemia. Nature Biotechnology, 31(6), 545-552. Google Scholar

Aprilis, N. (2017). Faktor-Faktor Yang Berhubungan Dengan Kekambuhan Pasien Gangguan Jiwa Di Rumah Sakit Jiwa Tampan Provinsi Riau Tahun 2016. Menara Ilmu, 11(77). Google Scholar

Bharucha, E. (2015). Textbook Of Environmental Studies. Universities Press (I) Pvt, Ltd, Hydrabad. Google Scholar

Fenton, J. J., Jerant, A. F., Bertakis, K. D., \& Franks, P. (2012). The Cost Of Satisfaction: A National Study Of Patient Satisfaction, Health Care Utilization, Expenditures, AndMortality. Archives Of Internal Medicine, 172(5), 405-411. Google Scholar

Gunawan, O., Gokmen, T., Warren, C. W., Cohen, J. D., Todorov, T. K., Barkhouse, D. A. R., Bag, S., Tang, J., Shin, B., \& Mitzi, D. B. (2012). Electronic Properties Of The Cu2znsn (Se, S) 4 Absorber Layer In Solar Cells As Revealed By Admittance Spectroscopy And Related Methods. Applied Physics Letters, 100(25), 253905. Google Scholar

Hardisal, R. M. (2017). Faktor Yang Berhubungan Dengan Kekambuhan Penderita Skizofrenia Di Rumah Sakit Jiwa Tampan Provinsi Riau. Menara Ilmu, 11(77). Google Scholar

Kemenkes, R. I. (2018). Hasil Utama Riskesdas 2018. In Online) Http://Www. Depkes. Go. Id/Resources/Download/InfoTerkini/Materi_Rakorpop_2018/Hasil\% 20riskesdas (Vol. 202018). Google 
Scholar

Maramis, R. K. (2013). Analisis KafeinDalam Kopi Bubuk Di Kota Manado Menggunakan Spektrofotometri Uv-Vis. Pharmacon, 2(4). Google Scholar

Mastiyas, Y. N. (2018). Hubungan Resiliensi Keluarga Dengan Kekambuhan Pada Orang Dengan Gangguan Jiwa (Odgj). Universitas Airlangga. Google Scholar

Notoatmdojo. (2014). Metodelogi Penelitian Kesehatan. Jakarta; Rineka Cipta. Google Scholar

Putri, S. P., Yamamoto, S., Tsugawa, H., \& Fukusaki, E. (2013). Current Metabolomics: Technological Advances. Journal of Bioscience And Bioengineering, 116(1), 9-16. Google Scholar

Riskesdas. (2013). Riskesdas 2013. In Jakarta Kementeri Kesehat Ri (Vol. 6). Google Scholar

Santika, T., Meijaard, E., Budiharta, S., Law, E. A., Kusworo, A., Hutabarat, J. A., Indrawan, T. P., Struebig, M., Raharjo, S., \& Huda, I. (2017). CommunityForest Management In Indonesia:
Avoided Deforestation In The Context Of Anthropogenic And Climate Complexities. Global Environmental Change, 46, 60-71. Google Scholar

Sari, D. P., \& Sholihah'Atiqoh, N. (2020). Hubungan Antara Pengetahuan Masyarakat Dengan Kepatuhan Penggunaan Masker Sebagai Upaya Pencegahan Penyakit Covid-19 Di Ngronggah. Infokes: Jurnal Ilmiah Rekam Medis Dan Informatika Kesehatan, 10(1), 52-55. Google Scholar

Wardhani, L. K., \& Sulistyani, N. (2012). Uji Aktivitas Antibakteri Ekstrak Etil Asetat Daun Binahong (Anredera Scandens (L.) Moq.) Terhadap Shigella Flexneri Beserta Profil Kromatografi Lapis Tipis. Jurnal Ilmiah Kefarmasian, 2(1), 1-6. Google Scholar

Yosep, I., Mediani, H. S., \& Lindayani, L. (2021). Working Alliance Among Mental Health Nurses In Indonesia: A Comparative Analysis Of SocioDemographic Characteristics. Belitung Nursing Journal, 7(2), 125-130. Google Scholar

\section{Copyright holder:}

Amran Sebayang (2021)

First publication right:

Jurnal Health Sains

This article is licensed under: 